\title{
Neuroendocrine Carcinoma of the Breast: Case Report and Literature Review
}

\author{
Yu-Chen Lee ${ }^{a, b}$ Yao-Li Chen ${ }^{b}$ Szu-Erh Chan ${ }^{c}$ Hsin-Shun Tseng ${ }^{b, d}$ Dar-Ren Chen ${ }^{b, d}$ \\ ${ }^{a}$ Division of General Surgery, Department of Surgery, Yumin Hospital, Nantou \\ ${ }^{\mathrm{b}}$ Division of General Surgery, Department of Surgery, \\ ${ }^{c}$ Department of Surgical Medicine, Erlin Branch, \\ ${ }^{d}$ Comprehensive Breast Cancer Center, Changhua Christian Hospital, Changhua, Taiwan, Republic of China
}

\section{Key Words \\ Neuroendocrine tumor · Synaptophysin · Breast}

\section{Summary}

Background: Neuroendocrine carcinoma of the breast is a rare disease. Case Report: We present a 65-yearold female patient with an enlarged breast mass within 2 months. Solid neuroendocrine carcinoma of the breast was diagnosed by excision biopsy and histopathological analysis. A lumpectomy with the right axillary sentinel lymph node biopsy was performed, and the mass was completely resected. The literature on neuroendocrine carcinoma of the breast is reviewed. Conclusion: Due to the diversity of imaging findings from primary breast neuroendocrine carcinomas, the diagnosis is based on immunohistochemical staining of neuroendocrine markers. Surgery has turned out to be the first-line treatment and subsequently radiation may play a role in palliative treatment.

\section{Background}

Primary neuroendocrine carcinoma of the breast is a rare entity. Reports of a breast tumor showing features of carcinoids date back to 1963 [1]. Since the first description by Cubilla and Woodruff in 1977 [2], less than 150 cases have been reported. These carcinomas mostly occur in elderly women. The diagnostic investigation commonly involves fine needle aspiration and histopathological analysis [3]. The tumor cells of mammary neuroendocrine carcinomas are argyrophilic but

\author{
Schlüsselwörter \\ Neuroendokriner Tumor · Synaptophysin · Brust
}

\section{Zusammenfassung}

Hintergrund: Neuroendokrine Mammakarzinome sind eine seltene Krankheit. Fallbericht: Wir stellen eine 65 Jahre alte Frau mit einem innerhalb von 2 Monaten vergrößerten Tumor vor. Ein solides neuroendokrines Karzinom der Brust wurde mittels Exzisionsbiopsie und histopathologischer Analyse diagnostiziert. Eine Lumpektomie wurde mit einer Sentinel-Lymphknotenbiopsie in der rechten Achsel durchgeführt und die Wucherung komplett entfernt. Die Literatur zum neuroendokrinen Mammakarzinom wird dargestellt. Schlussfolgerung: Aufgrund der Vielfältigkeit der Ergebnisse bei der Bildgebung des primären neuroendokrinen Mammakarzinoms basiert die Diagnose auf immunohistochemischer Färbung von neuroendokrinen Markern. Die chirurgische Entfernung hat sich als First-line-Behandlung herausgestellt und nachfolgend kann Bestrahlung eine Rolle in der palliativen Behandlung einnehmen.

not argentaffin and are found to contain dense-core secretory granules of various types ultrastructurally [4]. Here, we report a case of primary neuroendocrine carcinoma of the breast and review the literature.

\section{Case Report}

The 65-year-old woman had been in her usual state of health until 5 months previously, when she underwent a mammography screening. There was no family history of breast cancer. The mammography screen-

\section{KARGER}

Fax +497614520714

Information@Karger.de

www.karger.com (c) 2009 S. Karger GmbH, Freiburg

Accessible online at:

www.karger.com/brc
Prof. Dar-Ren Chen

Comprehensive Breast Cancer Center, Changhua Christian Hospital

135 Nanhsiao Street, Changhua 500, Taiwan, Republic of China

Tel. +886 4 723-8595 ext. 4871, Fax -1922

115045@cch.org.tw 
Fig. 1. Mammography results showed an ovoid, isodense mass. Left Mediallateral oblique view. Right Caudal-coronal view.
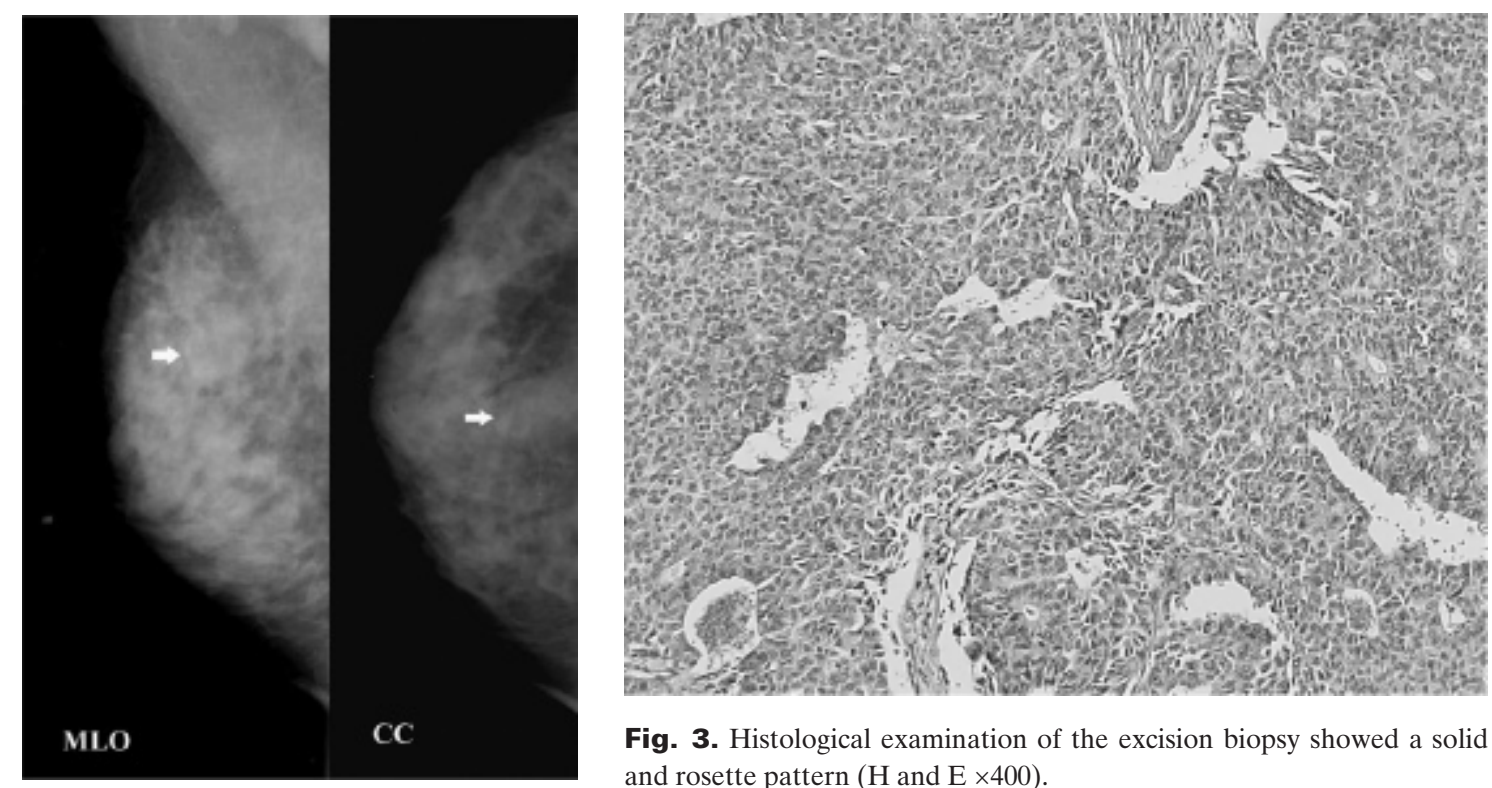

Fig. 3. Histological examination of the excision biopsy showed a solid and rosette pattern $(\mathrm{H}$ and $\mathrm{E} \times 400)$.
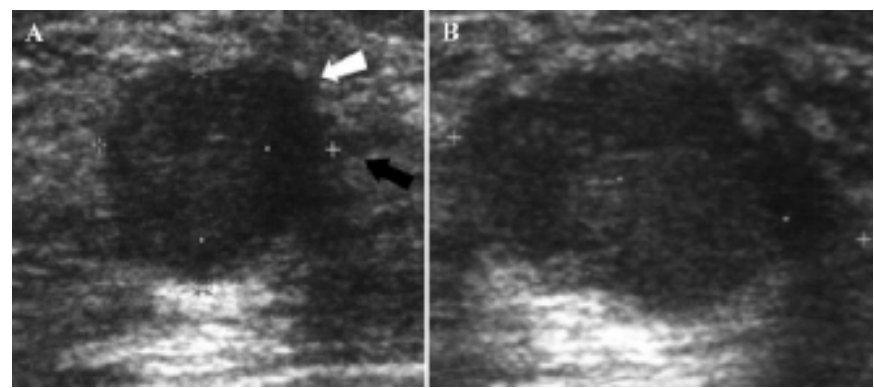

Fig. 2. A Right breast sonography showed an ovoid, hypoechoic mass with microlobulation (white arrow) and ductal extension (black arrow). B Sonography performed 2 months after the initial one, showing an irregular-shaped mass with daughter nodule.

ing (fig. 1) showed a $1.7 \times 1.2 \mathrm{~cm}$ ovoid, isodense, circumscribed, opaque nodule in the mid-portion of the right upper quadrant without microcalcification. Physical examination revealed a coarse, firm, fixed tumor above the right breast in the 12 o'clock position $2 \mathrm{~cm}$ from the nipple. Ultrasonography (fig. 2) revealed one ovoid, microlobulated, hypoechoic mass with posterior acoustic enhancement at the same site by palpation. Core needle biopsy showed only some atrophic mammary glands, and there was no evidence of malignancy. 2 months later, she came to our clinic because of the enlargement of the same mass. Ultrasonography (fig. 2) revealed a $2.5 \times 2.0 \mathrm{~cm}$ hypoechoic mass with daughter nodules and hypervascularity. Excisional biopsy was performed under local anesthesia. Neuroendocrine carcinoma was diagnosed by histological examination. Lumpectomy was done following sentinel lymph node biopsy (SLNB). Macroscopically, the tumor was pale yellow, measuring $1.6 \times 1.5 \mathrm{~cm}$ in dimension. Microscopically (fig. 3), the tumor cells were solid and rosette in pattern. Immunohistochemical staining (fig. 4) revealed positive for synaptophysin. The tumor cells were strongly estrogen receptor-positive $(\mathrm{ER}+)$, while progesterone receptor and HER-2 were negative. The sentinel lymph nodes were negative. The whole-body positron emission tomography (PET) scan showed no evidence of other primary sites or metastatic lesions.

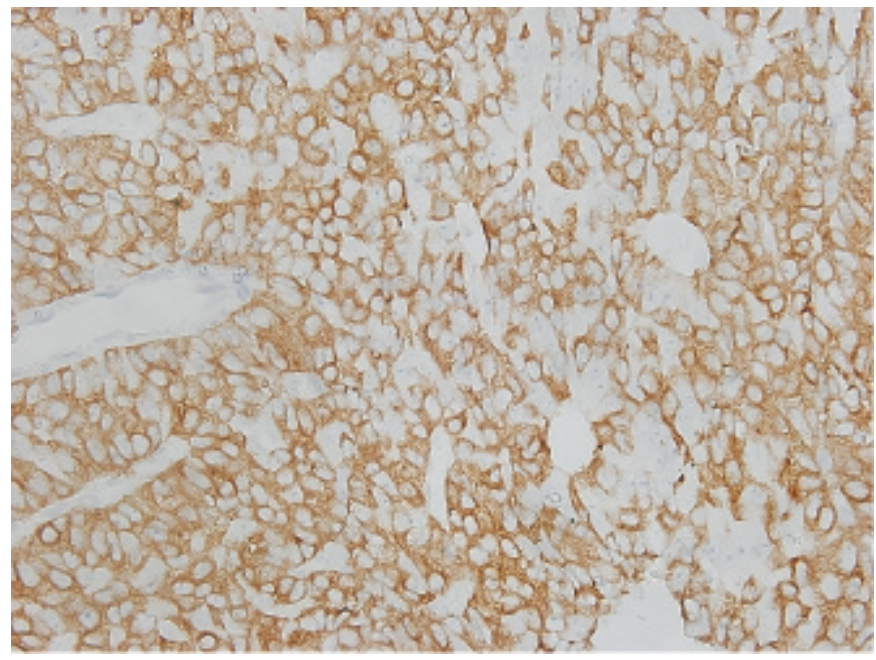

Fig. 4. Immunohistochemical stain of the excision biopsy showed synaptophysin positivity (anti-synaptophysin $\times 400$ ).

\section{Discussion}

In 1963, Feyrter and Hartmann [1] were the first to demonstrate argynoiphilia to describe 2 breast carcinomas with a neuroendocrine nature of mucoid carcinoid patterns. However, it was not until 1977 when Cubilla and Woodruff [5] announced that the granules in the tumor cells were of the neurosecretory type and classified a subset of breast carcinomas as 'carcinoid'. In 1982, Azzopardi [6] presented 14 cases among which the argyrophilic breast tumors appeared to be a wide range of morphological and histochemical forms.

It is well known that neuroendocrine elements can be found in ductal and lobular carcinoma. Unlike those in lungs 
or gastrointestinal tract, hyperplastic or benign neoplastic neuroendocrine lesions have never been reported in the breast, and all breast neuroendocrine lesions recorded so far have been considered carcinomas. Furthermore, breast endocrine lesions do not grow in unique histological patterns; instead, they often resemble other types of breast cancer and almost never duplicate the characteristics of gastrointestinal or pulmonary carcinoid [7]. This has led to the hypothesis that the neuroendocrine type of breast carcinomas does not arise from preexisting endocrine cells, but rather expresses a potentially differentiated pathway within breast carcinomas [7].

Scattered neuroendocrine cells can be found in 10-50\% of breast tumors, depending on the definition and the detection method [8]. However, pure neuroendocrine carcinoma in breasts is very rare. Günhan-Bilghen et al. [3] stated that the possibility was $0.27 \%$ in a series of 1,845 histopathologically proved breast carcinomas. Core needle biopsy was used for preoperative diagnosis and easily diagnosed the tumor using immunohistochemistry for neuroendocrine markers [9]. Our case was diagnosed with excisional biopsy. The initial core needle biopsy only removed 1 sample, and therefore it may have been off target. Primary neuroendocrine carcinoma of the breast was recently recognized as a distinct entity and was added to the World Health Organization (WHO) Classification of Tumors (2003) under the category of neuroendocrine tumors. The primary mammary neuroendocrine tumors show neuroendocrine markers in more than $50 \%$ of the tumor cells and thus can be distinctly separated from breast carcinoma with the focal endocrine differentiation method. Among the different types of neuroendocrine tumors, i.e. solid neuroendocrine carcinoma, atypical carcinoid tumors, small cell/oat cell carcinoma, large cell neuroendocrine carcinoma, our case was specifically the solid neuroendocrine carcinoma. This type of carcinoma consists of dense and solid nests or trabeculae of cells separated by delicate fibrovascular stroma. They occur mainly in older women around the age of 70 . Zekioglu et al. [10] reported a series of 12 cases with only 2 cases under 60 years old, and more than half of these patients were over 70 years old. Our case was a 65-year-old postmenopausal woman.

In neuroendocrine carcinomas, immunohistochemical studies for neuroendocrine markers have been recorded. Neuronspecific enolase (NSE), cytokeratins (AE1/AE3, CAM 5.2, or CK7), and neuroendocrine differentiation indicators, such as Grimelius stain, synaptophysin, Leu 7, serotonin, bombesin, and chromogranin A or B, are most commonly used [11]. The result in our case was evident with synaptophysin stain. Sapino and Bussolati [12] proposed that only tumors that express chromogranin $\mathrm{A}$, or chromogranin $\mathrm{B}$, or synaptophysin in more than $50 \%$ of their cells be recognized as endocrine breast tumors. Miremadi et al. [8] compared 3 markers, NSE, chromogranin A, and/or synaptophysin, and found them to have no relationship with established prognostic factors or patient outcome.

The imaging features of mammary neuroendocrine carcinomas can be very diverse. Wade et al. [13] reported the first case in 1983 , in which the mammography showed a $10-\mathrm{cm}$ multilobulated soft tissue mass with numerous ill-defined margins, while the sonography demonstrated both solid and cystic components of the mass. In 2000, Rubini et al. [14] described their case in mammography as a 5-cm high-density mass with irregular margin, however, in sonography as cystic with intracystic tracts. In 2003, Günhan-Bilgen et al. [3] reported the first mammographic and sonographic series (5 cases) of this rare tumor with pathological correlation. In most cases, mammography showed dense round masses with predominantly spiculated or lobulated margins correlating with the pathological margins. Most of the tumors were hypoechoic and of homogenous echo texture with normal sound transmission. Mammographically, our case was an isodense, circumscribed, opaque nodule, and sonographically, it was a hypoechoic mass with microlobulated margin, posterior acoustic enhancement, and hypervascularity. The mass did not contain any cystic components.

Treatment for neuroendocrine carcinomas is limited to surgery. Most reported cases involved lumpectomy or mastectomy with axillary lymph node dissection. In our case, lumpectomy was performed with axillary SLNB. The frozen section for SLNB was negative for malignancy. Radiotherapy is not effective for carcinoid tumors and no reports of adjuvant radiation for primary mammary neuroendocrine carcinomas have been recorded. However, chemotherapy can be effective for this type of tumor [15]. The tumor was ER+ and the patient has been taking tamoxifen after the surgery. Our patient did not receive any chemotherapy due to the small size of the tumor and negative axillary node status.

Finally, primary breast neuroendocrine carcinomas are rarely found and mainly in older women over 60 years old. Due to the diversity of imaging findings, the diagnosis is based on immunohistochemical stain in neuroendocrine markers. Surgery has turned out to be the first-line treatment and subsequently radiation may play a role in palliative treatment.

\section{Conflict of Interest}

The authors declare that they have no competing interests. 


\section{References}

1 Feyrter F, Hartmann G: On the carcinoid growth form of the carcinoma mammae, especially the carcinoma solidum (gelatinosum) mammae (article in German). Frankf Z Pathol 1963;73:24-39.

2 Modlin IM, Shapiro MD, Kidd M: An analysis of rare carcinoid tumors: clarifying these clinical conundrums. World J Surg 2005;29:92-101.

3 GÜnhan-Bilgen I, Zekioglu O, UstÜn EE, Memis A, Erhan Y: Neuroendocrine differentiated breast carcinoma: imaging features correlated with clinical and histopathological findings. Eur Radiol 2003;13: 788-793.

4 Rosai J: Breast; in Rosai J (ed): Rosai and Ackerman's Surgical Pathology. Philadelphia, Elsevier, 2004, pp 1810-1811.

$\checkmark 5$ Cubilla AL, Woodruff JM: Primary carcinoid tumor of the breast: a report of 8 patients. Am J Surg Pathol 1977;1:283-292.
6 Azzopardi JG, Muretto P, Goddeeris P, Eusebi V, Lauweryns JM: 'Carcinoid' tumours of the breast: the morphological spectrum of argyrophil carcinomas. Histopathology 1982;6:549-569.

7 Maluf HM, Koerner FC: Carcinomas of the breast with endocrine differentiation: a review. Virchows Arch 1994;425:449-457.

8 Miremadi A, Pinder SE, Lee AH, Bell JA, Paish EC, Wencyk P, Elston CW, Nicholson RI, Blamey RW, Robertson JF, Ellis IO: Neuroendocrine differentiation and prognosis in breast adenocarcinoma. Histopathology 2002;40:215-222.

9 Fujimoto Y, Yagyu R, Murase K, Kawajiri H, Ohtani H, Arimoto Y, Yamamura T, Inoue T, Moritani S: A case of solid neuroendocrine carcinoma of the breast in a 40-year-old woman. Breast Cancer 2007;14:250-253.

10 Zekioglu O, Erhan Y, Ciris M, Bayramoglu H: Neuroendocrine differentiated carcinomas of the breast: a distinct entity. Breast 2003;12:251-257.
1 Papotti M, Gherardi G, Eusebi V, Pagani A, Bussolati G: Primary oat cell (neuroendocrine) carcinoma of the breast. Report of four cases. Virchows Arch A Pathol Anat Histopathol 1992;420:103-108.

12 Sapino A, Bussolati G: Is detection of endocrine cells in breast adenocarcinoma of diagnostic and clinical significance? Histopathology 2002;40:211214.

13 Wade PM Jr, Mills SE, Read M, Cloud W, Lambert MJ 3rd, Smith RE: Small cell neuroendocrine (oat cell) carcinoma of the breast. Cancer 1983;52:121125 .

4 Rubini G, D'Eredita G: Tc-99m sestamibi and in111 dtpa octreotide uptake in breast carcinoma with neurendocrine differentiation. Clin Nucl Med 2000;25:482-483.

15 Yalcin S, Zengin N, Tekuzman G, Kucukali T: Primary neuroendocrine tumor of the breast. Med Oncol 1997;14:121-123. 